\title{
Rapid and Selective Uptake, Metabolism, and Cellular Distribution of Docosahexaenoic Acid among Rod and Cone Photoreceptor Cells in the Frog Retina
}

\author{
Elena B. Rodriguez de Turco, Wiliam C. Gordon, and Nicolas G. Bazan \\ LSU Eye Center and Neuroscience Center, Louisiana State University Medical Center School of Medicine, New Orleans, \\ Louisiana $70112-2234$
}

The uptake, metabolism, and cellular distribution of ${ }^{3} \mathrm{H}$-docosahexaenoic acid $\left({ }^{3} \mathrm{H}-22: 6\right)$ in the frog retina during in vitro incubation were studied. An initial diffuse labeling throughout the retina was detected by autoradiography and was followed by an active steady increase in labeled photoreceptor cells. After $6 \mathrm{hr}$ of incubation, $92 \%$ of the label was concentrated in photoreceptor cells. Among these cells, 435rods (green rods) labeled heavily and showed two to three times higher uptake than the 502-rods (red rods). Cone uptake labeling was the lowest, showing negligible labeling throughout the cytoplasm. However, oil droplets of the 575cones actively concentrated 22:6. The high uptake of ${ }^{3} \mathrm{H}-22: 6$ by photoreceptor cells was followed by its rapid esterification into phospholipids. After $6 \mathrm{hr}$ of labeling, only $5 \%$ of the radioactivity in the retina was free $22: 6$, whereas $88 \%$ was esterified into phospholipids. The remaining 22:6 was distributed equally in triacylglycerols (TAGs) and diacylglycerols. When ${ }^{3} \mathrm{H}-22: 6(0.11 \mu \mathrm{M})$ of high specific activity was used, early incubation times showed phosphatidylinositol (PI) labeling to be of the same order of magnitude or greater than that of phosphatidylcholine (PC) or phosphatidylethanolamine (PE). Although the amount of endogenous 22:6 esterified into PI accounted for less than $2 \%$ of the 22:6 in retinal phospholipids, $27 \%$ of ${ }^{3} \mathrm{H}-22: 6$ labeling was recovered in this phospholipid. When ${ }^{14} \mathrm{C}-22: 6$ at a final concentration of $70 \mu \mathrm{M}$ was used, a different profile of lipid labeling was observed. Forty percent of the labeling remained in the free fatty acid pool, followed by TAG $(24 \%)$, PC $(14 \%)$, and PE $(12 \%)$. PI showed the smallest increase in picomoles of ${ }^{14} \mathrm{C}$ 22:6 incorporated, when compared with ${ }^{3} \mathrm{H}-22: 6$.

In conclusion, a selective and differential uptake of ${ }^{3} \mathrm{H}$ 22:6 by photoreceptor cells is coupled to its active utilization for phospholipid biosynthesis, mainly that of PC, PE, and PI. The differential uptake of ${ }^{3} \mathrm{H}-22: 6$ among photoreceptor cells may reflect involvement of this fatty acid in cell-specific functions.

Received Apr. 22, 1991; revised June 19, 1991; accepted June 27, 1991.

This research was supported by United States Public Health Service Grants EY04428 and EY02377 from the National Eye Institute, National Institutes of Health, Bethesda, Maryland.

Correspondence should be addressed to Nicolas G. Bazan, M.D., Ph.D., LSU Eye Center and Neuroscience Center, 2020 Gravier Street, Suitc B, Ncw Orlcans, LA 70112-2234.

Copyright (C) 1991 Society for Neuroscience $0270-6474 / 91 / 113667-12 \$ 05.00 / 0$
Membrane phospholipids of photoreceptor cells, synapses, and other cellular structures of the nervous system avidly take up and retain docosahexaenoyl (22:6) chains, suggesting an important role for this fatty acid. Among the fatty acids that make up excitable membrane lipids, 22:6 is unique for several reasons. This nutritionally derived essential fatty acid of the n-3 family accounts for over $50 \%$ of retinal fatty acids. High concentrations of 22:6 are present in outer segments of photoreceptors (Aveldaño de Caldironi and Bazan, 1980; Fliesler and Anderson, 1983; Wiegand and Anderson, 1983; Aveldaño, 1989) and, more specifically, in disk membranes, where rhodopsin is located (Boesze-Battaglia and Albert, 1989). Uptake studies with ${ }^{3} \mathrm{H}-$ 22:6 demonstrate that, while all retinal cell types contain this fatty acid, $63 \%$ (human) to $94 \%$ (frog) of the total is actively taken up by photoreceptor cells. Despite the fact that $22: 6$ is a highly unsaturated fatty acid that can be readily oxidized, retina and brain retain high amounts of it, rather than substituting a more saturated, stable fatty acid. Significantly, disorders that include photoreceptor cell degeneration, such as Usher's syndrome, exhibit lowered blood plasma levels of 22:6 (Bazan et al., 1986). Finally, long-term maternal dietary deprivation of the $n-3$ fatty acid family results in measurable alterations in electroretinogram components, as well as in visual acuity (Wheeler et al., 1975; Neuringer et al., 1984, 1986). Highly unsaturated phospholipids provide a necessary environment for light-evoked changes in rhodopsin and other events of photoand neural transduction. Therefore, 22:6 is extremely important to excitable membrane function.

In frogs injected systemically with ${ }^{3} \mathrm{H}-22: 6$, the fatty acid is actively taken up by photoreceptor cells, where it becomes incorporated into the phospholipids (Gordon and Bazan, 1990). The label accumulates at the basc of the outcr segments of photoreceptor cells; this is followed by an expansion of the radioactive region toward the apex as a function of time of rod outer segment (ROS) renewal, which is probably due to a sustained and efficient supply of ${ }^{3} \mathrm{H}-22: 6$ from the liver (Scott and Bazan, 1989). The migration rate of the leading edge of the ${ }^{3} \mathrm{H}$ 22:6 phospholipids and that of the ${ }^{3} \mathrm{H}$-leucine-rhodopsin were very similar, suggesting that labeled 22:6 phospholipids and rhodopsin molecules incorporated into new disk membranes at the base of the ROSs coexist until shed from the tips of the ROSs into the retina pigment epithelium (RPE) (Gordon and Bazan, 1990). Moreover, this reflects that membrane replacement rather than molecular replacement (Young, 1974, 1976; Fliesler and Anderson, 1983) may be involved in the renewal 


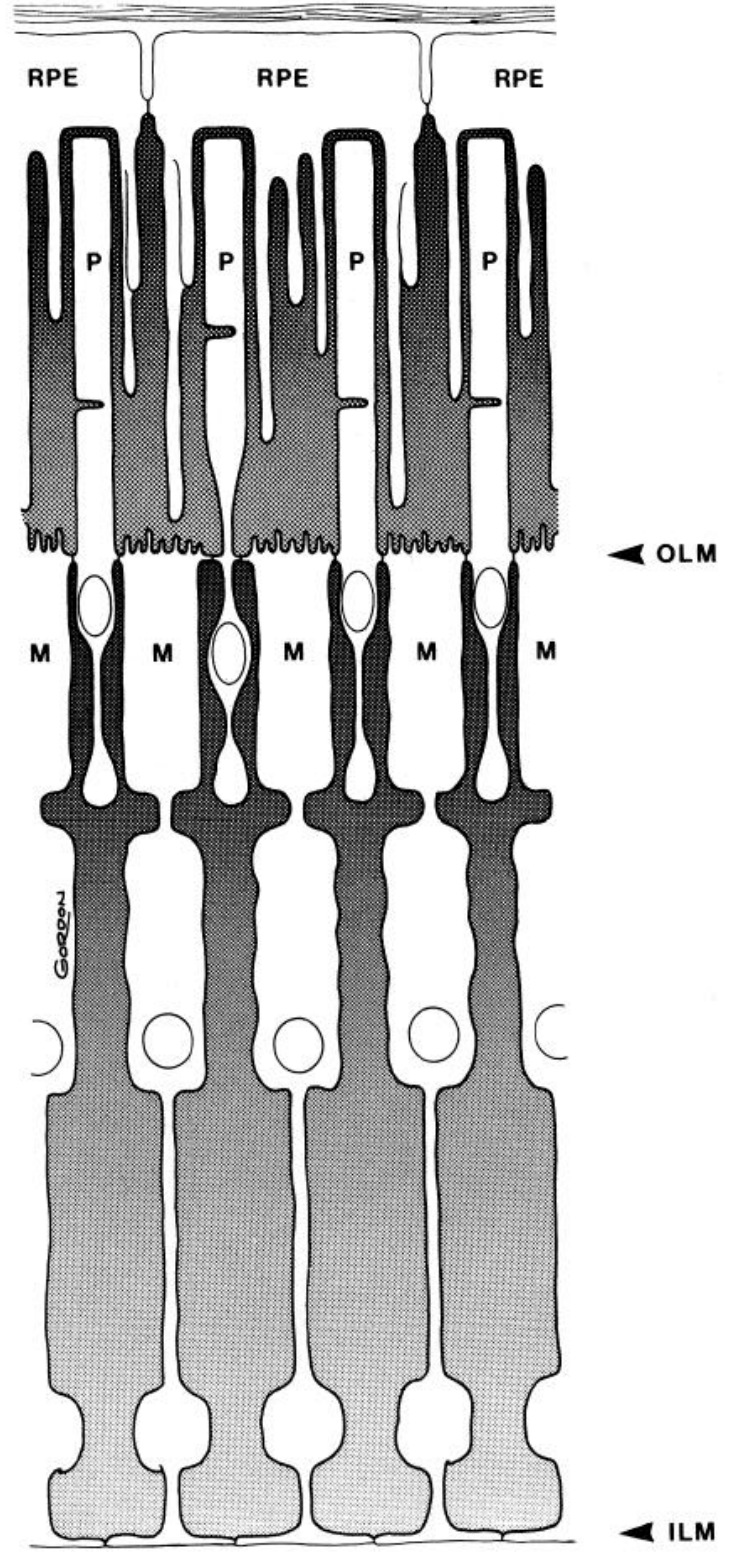

Figure 1. Diagram of frog retinal intercellular spaces, RPE, rod photoreceptor cells $(P)$, and Müller cells $(M)$. Tight junctions formed by these cells make up the outer limiting membrane $(O L M)$ and the inner limiting membrane (ILM), which divide the intercellular space into two isolated chambers (shaded areas). The outer chamber surrounds the photoreceptor outer and inner segments, while the inner chamber surrounds the photoreceptor terminals and the cells of the neural retina. These cells are drawn to scale.

of 22:6-containing molecular species of phospholipids closely associated with rhodopsin.

The RPE and Bruch's membrane separate the photoreceptor outer segments from the circulatory system of the choriocapillaris, thereby controlling nutrient input to photoreceptor cells. Müller cells traverse the retina, forming the inner and outer limiting membranes with tight junctions. The retina is thus compartmentalized into two relatively isolated extracellular chambers (Fig. 1). One contains the neural retina and all synaptic layers, while the other surrounds the inner and outer segments of the photoreceptor cells. All molecular traffic through the retina must cross at some time one or both of these compartments.
In fact, 22:6 may preferentially label photoreceptor outer segments due to specific transport mechanisms through the RPE and the extracellular spaces surrounding both the photoreceptors and the cells of the neural retina (Bazan et al., 1985a; Bazan and Cai, 1990; Gordon and Bazan, 1990). The present study describes ${ }^{3} \mathrm{H}-22: 6$ incorporation into the cells of these compartments.

We used in vitro frog retina to focus on the kinetics of the initial uptake of ${ }^{3} \mathrm{H}-22: 6$. In this model, we studied the synthesis of neutral lipids and individual phospholipids containing 22:6. In addition, we correlated the metabolism of $22: 6$ with its cellular distribution by using autoradiography.

\section{Materials and Methods}

Materials. The following reagents and materials were used: ${ }^{3} \mathrm{H}-22: 6$, specific activity of $17.9 \mathrm{Ci} / \mathrm{mmol}$, and ${ }^{14} \mathrm{C}-22: 6$, specific activity of 58 $\mathrm{mCi} / \mathrm{mmol}$ (New England Nuclear-Du Pont, Boston, MA); lipid standards and $14 \%$ boron trifluoride in methanol (Sigma, St. Louis, MO); precoated silica gel $\mathrm{H}$ and GHL plates (Analtech, Newark, NJ); Ready Gel and Ready Value (Beckman, Fullerton, CA); and analytical-grade solvents (Mallinckrodt, Paris, NY; Baker, Phillipsburg, NJ).

Animals. Frogs (Rana pipiens, northern variety; J. M. Hazen and Co., Alberg, VT) were maintained in plastic cages at $26^{\circ} \mathrm{C}$ on a diurnal cycle of $14 \mathrm{hr}$ light $/ 10 \mathrm{hr}$ dark for a minimum of 1 month prior to experiments. Fluorescent lights (G.E. cool white) supplied an average intensity of 15 $\mu \mathrm{E} / \mathrm{m}^{2} \cdot \sec \left(9 \times 10^{18}\right.$ photons $\left./ \mathrm{m}^{2} \cdot \mathrm{sec}\right)$ to the cages. Animals were fed crickets (Fluker's, Baton Rouge, LA) ad libitum once each week. Handling and maintenance of frogs were as previously described (Gordon and Bazan, 1990; Gordon and Dahl, 1990).

Isolation and incubations of retinas. Prior to the experiments, animals were kept in constant light overnight. After $1 \mathrm{hr}$ of darkness, eyes were removed under dim red light, and retinas were isolated from the RPE. The dark period allowed effective separation of RPE cells from retinas and ensured that retinas had identical photic histories prior to incubation. Control animals, given $24 \mathrm{hr}$ of light and $1 \mathrm{hr}$ of darkness, followed by an additional $1 \mathrm{hr}$ of light, routinely shed phagosomes from the tips of $30-40 \%$ of their ROSs. Excised retinas were kept in cold buffer until dissections were completed.

The incubation medium was a modified Ringer's-bicarbonate buffer, $\mathrm{pH} 7.2$, with the following composition (in $\mathrm{mm}$ ): $\mathrm{NaCl}, 120 ; \mathrm{KCl}, 5.1$; $\mathrm{KH}_{2} \mathrm{PO}_{4}, 1.25 ; \mathrm{CaCl}_{2}, 2.75 ; \mathrm{MgSO}_{4}, 1.25 ; \mathrm{NaHCO}_{3}, 25$; glucose, 11 . Prior to use, the buffer was gassed for at least $30 \mathrm{~min}$ with $95 \% \mathrm{O}_{2}, 5 \%$ $\mathrm{CO}_{2}$ and supplemented with $10 \%(\mathrm{v} / \mathrm{v})$ amphibian tissue culture medium (GIBCO, Grand Island, NY), according to the procedure of Fliesler and Basinger (1987). Three retinas were transferred to each flask and preincubated in $5 \mathrm{ml}$ of buffer at $25^{\circ} \mathrm{C}$ with mild shaking for $5 \mathrm{~min}$ under dim red light. The light was then turned on, and $2 \mu \mathrm{Ci} / \mathrm{ml}{ }^{3} \mathrm{H}$ 22:6 were added (final concentration, $0.11 \mu \mathrm{M}$ ). Incubations were conducted (15 min to $6 \mathrm{hr}$ ) under a constant stream of humidified $95 \% \mathrm{O}_{2}$, $5 \% \mathrm{CO}_{2}$. At the end of incubation, retinas were carefully transferred to fresh medium in a sequence of three Petri dishes to wash adsorbed 22:6 from the tissue. Each retina was divided into two portions; one half was used for biochemical analysis, and the other half, for histologic and autoradiographic studies.

Incorporation of ${ }^{3} \mathrm{H}-22: 6$ into retinal glycerolipids. Retinas were homogenized in chloroform : methanol $(2: 1, \mathrm{v} / \mathrm{v})$, and lipids were extracted (Marcheselli and Bazan, 1990). Lipid extracts were dried under nitrogen and resuspended in a known volume of chloroform: methanol (2:1, $\mathrm{v} / \mathrm{v}$ ), and aliquots were counted for total lipid labeling and for the separation of phospholipids and neutral lipids. Lipid extracts were spotted on precoated silica gel $\mathrm{H}$ plates (Analtech, Newark, NJ), and phospholipids were isolated (Marcheselli and Bazan, 1990). Two samples were run in each $20 \times 20 \mathrm{~cm}$ plate. For separation of neutral lipids, aliquots were applied to a silica gel GHL plate and resolved by monodimensional thin-layer chromatography (TLC) using hexane: ether: acetic acid $(70: 30: 2.3, \mathrm{v} / \mathrm{v} / \mathrm{v})$. The plates were visualized by brief exposure to iodine vapor, the spots were scraped into vials, and the silica gel was dispersed in $1 \mathrm{ml}$ of water. The vials were kept for at least $4 \mathrm{hr}$ at $45^{\circ} \mathrm{C}$ to allow the elution of lipids adsorbed to the silica gel. Ready Gel $(12 \mathrm{ml})$ was added, and the radioactivity was determined in a liquid scintillation counter (Beckman, Fullerton, CA). The lipid-free tissue residue was dissolved in $\mathrm{NaOH}(1 \mathrm{~N})$, and protein content was assessed 


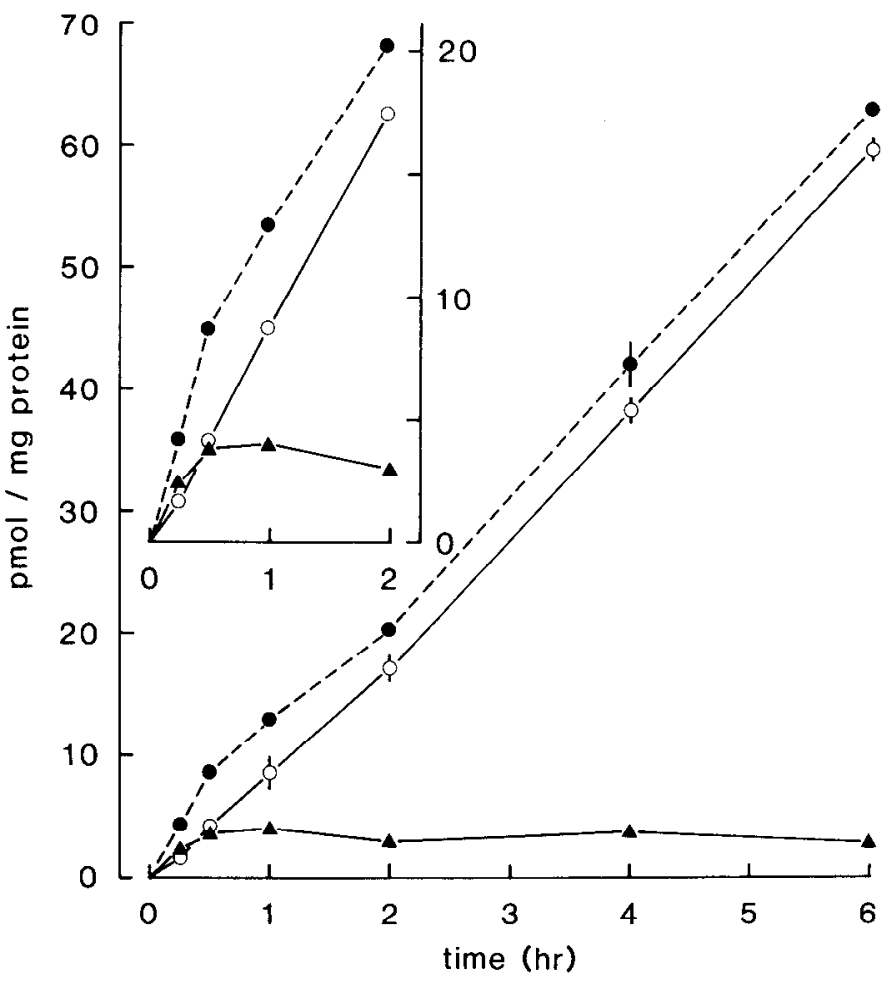

Figure 2. Kinetics of uptake and esterification of ${ }^{3} \mathrm{H}-22: 6$ in the frog retina as a function of incubation time. Retinas were incubated in the presence of ${ }^{3} \mathrm{H}-22: 6(2 \mu \mathrm{Ci} / \mathrm{ml}$; final concentration, $110 \mathrm{nM})$ for different periods of time. Lipids were extracted and isolated by TLC, and the radioactivity was determined. Values are the average of three individual samples; \pm SD is shown when it exceeds the size of the symbols. The inset shows uptake over the first $2 \mathrm{hr}$ in greater detail. Free ${ }^{3} \mathrm{H}-22: 6$ (A) labeling recovered in the free fatty acid pool. Esterified ${ }^{3} \mathrm{H}-22: 6$ (o) labeling recovered in neutral lipids and phospholipids. Total ${ }^{3} \mathrm{H}-22: 6$ (•) labeling (free + esterified).

(Marcheselli and Bazan, 1990) with bovine serum albumin used as a standard.

Analysis of fatty acyl composition of phospholipids. Phospholipids were separated by TLC. The plates were sprayed with $0.005 \% 2^{\prime}, 7^{\prime}$ dichlorofluorescein in methanol, and the spots were visualized under UV light. The fatty acids esterified into phospholipids were derivatized to methyl esters with $14 \% \mathrm{BF}_{3}$ in methanol and quantified by capillary gas-liquid chromatography (GLC) with an internal standard of methyl nonadecanoate (Marcheselli and Bazan, 1990).

Histology and autoradiography. After incubations and rinsing, retinas were transferred to cold fixative composed of $2 \%$ glutaraldehyde and $2 \%$ paraformaldehyde in $0.1 \mathrm{~m}$ sodium cacodylate buffer $(\mathrm{pH} 7.3)$. The next day, tissue was rinsed $(3 \times 15 \mathrm{~min})$ in $0.1 \mathrm{M}$ buffer, postfixed for $1 \mathrm{hr}$ in $1 \% \mathrm{OsO}_{4}$, rinsed in buffer $(3 \times 15 \mathrm{~min})$, and dehydrated through an ethanol series to acetone. Retinas were embedded in Polybed/Araldite plastic, and $1 \mu \mathrm{m}$ sections were cut with glass knives. Tissue was arranged to best show longitudinal views of photoreceptors and stained for contrast with $1 \%$ toluidine blue in $1 \%$ boric acid. All photomicrography was performed on a Zeiss Axioskop (Carl Zeiss, NY) using Kodak $35 \mathrm{~mm}$ Panatomic-X film (Gordon and Bazan, 1990).

Well-oriented 1- $\mu \mathrm{m}$-thick plastic sections were placed on cleaned glass slides and coated with NT-B2 emulsion (Kodak). Slides were stored in black boxes at $4^{\circ} \mathrm{C}$ for $1-5$ weeks, developed in Dektol, and stained for contrast with toluidine blue. Photographs were taken as described above, and subsequent analysis was performed on these pictures. All photography for grain analysis was performed at $1000 \times$ (microscope magnification); enlargement of negatives was kept constant to ensure equal magnification among the final prints. Each retinal picture, therefore, represented a random sample equal in size to other pictures. Silver grain positions were transferred manually to clear acetate overlays. Grain numbers were recorded for each of the retinal areas: outer segments,

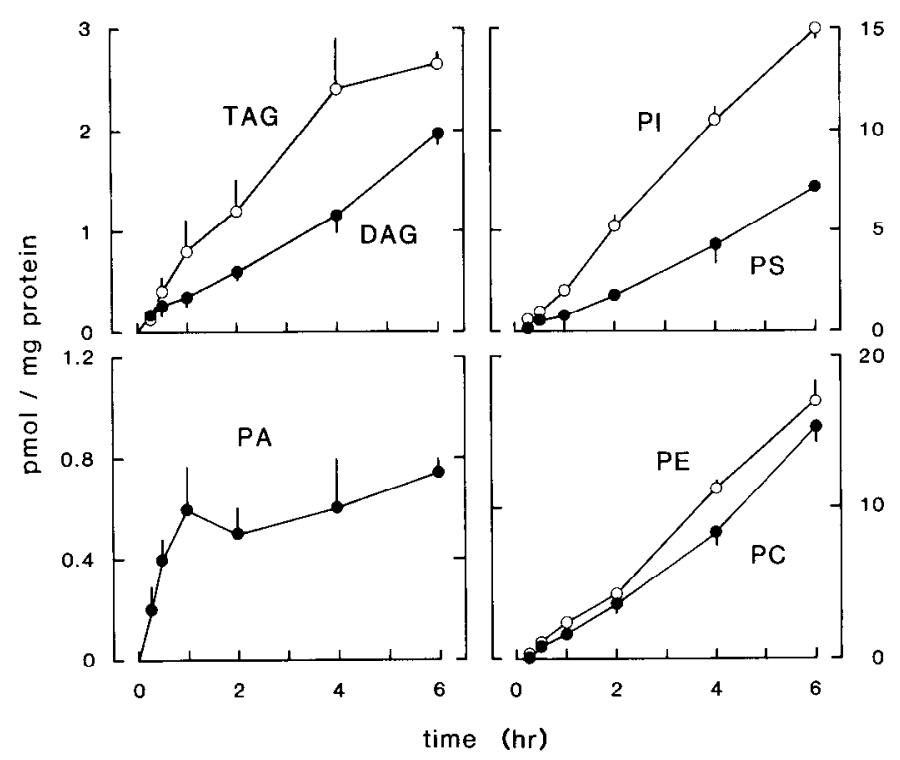

Figure 3. Kinetics of ${ }^{3} \mathrm{H}-22: 6$ incorporation into individual glycerolipids of frog retina as a function of time. Values are the average of three individual samples; $\pm \mathrm{SD}$ is shown. Other details are as in Figure 2.

inner segments, ellipsoids, total photoreceptor cells, and neural retina. When the total grain count for each picture was normalized to $100 \%$, the rclativc pcrcent labeling within each retinal region could be calculated. Two different samples from each retina and two different time series were analyzed in this way. The calculated percentages for the retinal areas were then averaged to give final values.

\section{Results}

Removal of ${ }^{3} \mathrm{H}-22: 6$ from the free 22:6 pool, and esterification into retinal glycerolipids during in vitro incubation

Free ${ }^{3} \mathrm{H}-22: 6$ was rapidly taken up by frog retina and incorporated into glycerolipids during in vitro incubations. The labeling of glycerolipids from retinas incubated with $110 \mathrm{nM}{ }^{3} \mathrm{H}-22: 6$ was monitored up to $6 \mathrm{hr}$. The profile of total ${ }^{3} \mathrm{H}-22: 6$ recovered from the retina (Fig. 2, broken line) demonstrated an early, rapid uptake ( $0-30 \mathrm{~min}$ ), followed by a slower phase (up to $2 \mathrm{hr}$ ), and finally a sustained increase of labeling, up to the last time analyzed $(6 \mathrm{hr})$. The free ${ }^{3} \mathrm{H}-22: 6$ pool in the retina reached its highest level at 30-60 min, accounting for $50 \%$ and $33 \%$, respectively, of the total radioactivity recovered from retinal lipids. By $2 \mathrm{hr}$, the level of free ${ }^{3} \mathrm{H}-22: 6$ significantly decreased and remained unchanged during the subsequent $4 \mathrm{hr}$ of incubation. After $6 \mathrm{hr}$, only $5 \%$ (mass, $3 \mathrm{pmol} /$ retina) of the total labeling was recovered as free ${ }^{3} \mathrm{H}-22: 6(0.001 \%$ of total retinal $22: 6-$ containing lipids). The changes in the precursor-labeled pool were paralleled by very active esterification of ${ }^{3} \mathrm{H}-22: 6$ into glycerolipids. The apparent rate of esterification within the first 2 $\mathrm{hr}$ was $8.6 \mathrm{pmol} / \mathrm{mg}$ protein $/ \mathrm{hr}$. After $2 \mathrm{hr}$, this value was 10.8 $\mathrm{pmol} / \mathrm{mg}$ protein $/ \mathrm{hr}$, suggesting the accessibility of ${ }^{3} \mathrm{H}-22: 6$ to different metabolic pools within retinal cells and/or to different cellular and subcellular compartments.

\section{Rapid incorporation of ${ }^{3} \mathrm{H}-22: 6$ into retinal phospholipids}

${ }^{3} \mathrm{H}-22: 6$ was rapidly incorporated into phospholipids. From the earliest time analyzed ( $15 \mathrm{~min})$ up to the latest time (6 hr), $84 \%$ and $92 \%$, respectively, of the total esterified ${ }^{3} \mathrm{H}-22: 6$ were recovered in phospholipids. Kinetics of individual glycerolipids showed distinctive profiles (Fig. 3). Phosphatidic acid (PA) labeling was very active at the earliest times and reached a plateau 


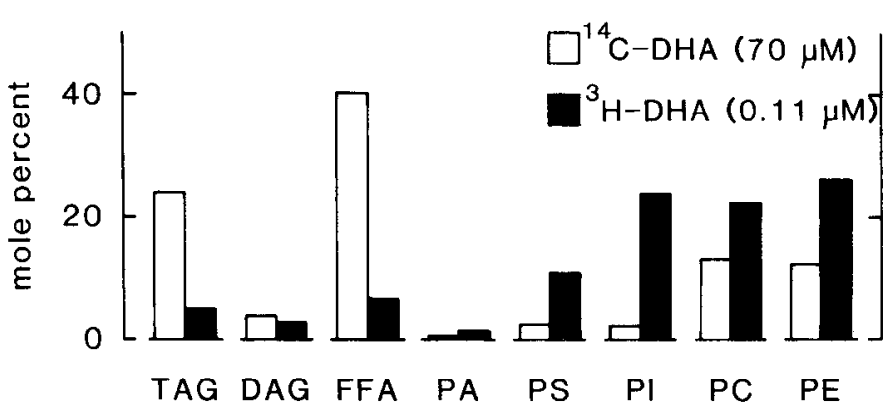

Figure 4. Distribution as mole percent of 22:6 within lipids of the retina after labeling with high ${ }^{14} \mathrm{C}-22: 6$ concentration $(70 \mu \mathrm{M})$ and with low ${ }^{3} \mathrm{H}-22: 6$ concentration $(0.11 \mu \mathrm{M})$. $D H A, 22: 6 ; F F A$, free fatty acid.

by $1 \mathrm{hr}$. Diacylglycerol (DAG) labeling, however, reflected a sustained uptake of label through $6 \mathrm{hr}$ of incubation. Triacylglycerols (TAGs) showed early active uptake of label but reached a plateau after $4 \mathrm{hr}$. Of the total esterified ${ }^{3} \mathrm{H}-22: 6,80 \%$ was accounted for in phosphatidylethanolamine (PE), phosphatidylcholine (PC), and phosphatidylinositol (PI). Phosphatidylserine (PS) labeling was slow but sustained, amounting to about $10 \%$ of the esterified ${ }^{3} \mathrm{H}-22: 6$. PI showed its highest uptake between 1 and $2 \mathrm{hr}$. By $2 \mathrm{hr}$, PI labeling accounted for $30 \%$ of the total esterified ${ }^{3} \mathrm{H}-22: 6$, followed by $\mathrm{PE}(24 \%)$ and $\mathrm{PC}(22 \%)$. $\Lambda$ fter $6 \mathrm{hr}$, a relatively higher uptake into $\mathrm{PE}$ and $\mathrm{PC}$ than into PI was reflected in the percent distribution of ${ }^{3} \mathrm{H}-22: 6$ (PI, 25\%; PC, 26\%; PE, 28\%).

The fatty acid composition of phospholipids in the frog retina (Table 1) showed a high content of 22:6 (e.g., 22:6 accounted for $18 \%$ of the acyl groups of PI). This is in agreement with data obtained from toad retina (Aveldaño and Bazan, 1977; Aveldaño de Caldironi and Bazan, 1980) and isolated ROS of the frog (Fliesler and Anderson, 1983). When the percent mass and labeling distribution of 22:6 among phospholipids are compared, the avid uptake of ${ }^{3} \mathrm{H}-22: 6$ into PI becomes even more evident (Table 2). The relative "specific activity" of PI was approximately 17-25 times greater than that of PS, PC, and PE, and only 11 times greater than that of PA, the lipid with the second highest relative uptake of ${ }^{3} \mathrm{H}-22: 6$. Therefore, the very high, early incorporation of ${ }^{3} \mathrm{H}-22: 6$ into PA and PI suggests that 22:6-containing molecular species of these lipids display very active de novo synthesis and/or turnover.

When retinas were incubated in vitro with ${ }^{14} \mathrm{C}-22: 6$ (final concentration, $70 \mu \mathrm{M}$ ), a different profile of lipid labeling was ob- served (Fig. 4). After $5 \mathrm{hr}$ of incubation, $40 \%$ of the precursor remained in the free fatty acid pool, and TAG accounted for the highest proportion of esterified ${ }^{14} \mathrm{C}-22: 6$ (24\%), followed by PC (14\%) and PE (12\%). Differences in total esterified 22:6 (832 $\mathrm{pmol} / \mu \mathrm{g} \mathrm{P}$ for ${ }^{14} \mathrm{C}-22: 6$, as compared to $4.1 \mathrm{pmol} / \mu \mathrm{g} \mathrm{P}$ for ${ }^{3} \mathrm{H}$ $22: 6$ ) were mainly due to its higher incorporation into TAG, DAG, PC, and PE (1000-, 263-, 120-, and 100-fold greater labeling than that of ${ }^{3} \mathrm{H}-22: 6$, respectively), while PI was the phospholipid that showed the lowest increase in ${ }^{14} \mathrm{C}$ labeling (20-fold).

\section{Cellular distribution of ${ }^{3} \mathrm{H}-22: 6$ in the frog retina}

Predominant uptake of ${ }^{3} \mathrm{H}-22: 6$ by photoreceptor cells was demonstrated by autoradiography in timed incorporation studies (Figs. 5, 6). After 30 min of incubation with ${ }^{3} \mathrm{H}-22: 6$, the myoid region of rod photoreceptor cells began to label (Fig. $6 \mathrm{~B}$, arrowhead). Initial accumulation within the ellipsoid region occurred in 1-2 hr. By $4 \mathrm{hr}$, label appeared in the perinuclear cytoplasm and axonal regions, and by $4-6 \mathrm{hr}$ the synaptic terminals were labeled. Cone oil droplets also began to accumulate label by this time. Throughout this incubation period, label continued to accumulate in the rod cell ellipsoids (Fig. $6 E, F$ ). ROSs continued to label diffusely.

Long-exposure autoradiograms revealed punctate regions of dense label in the outer plexiform layer corresponding to the photoreceptor synaptic terminals (Figs. 5, 7A), indicating that once the fatty acid was incorporated into the inner segments, some went to the base of the outer segments and some to the synaptic endings. Occasionally, the nuclei were well outlined in some rod cells (Fig. $7 A$, arrowheads). When traced through serial autoradiographic sections, they were shown to connect with the heavily labeled ellipsoid regions proximal to the outer segments. Faint banding was sometimes observed within the inner plexiform layer, and slightly greater labeling occurred in the nerve fiber layer.

The total retinal activity ( $\mathrm{dpm} / \mathrm{mg}$ protein of retinal lipids) for each incubation time indicated an overall increase in retinal uptake from $15 \mathrm{~min}$ to $6 \mathrm{hr}$. An increase in autoradiographic silver grains was observed throughout the retina on representative sections for each of these incubation times. Therefore, as shown in Figure $8 A$, rates of uptake of ${ }^{3} \mathrm{H}-22: 6$, as calculated from the biochemical analysis and the autoradiographic analysis, are very similar, and allow results of these two experimental methods to be compared.

Analysis of the autoradiographic distribution of retinal silver

Table 1. Acyl group composition of phospholipids from frog retina

\begin{tabular}{lrrrrr} 
Fatty acid & \multicolumn{1}{c}{ PA } & \multicolumn{1}{c}{ PS } & \multicolumn{1}{c}{ PI } & \multicolumn{1}{c}{ PC } & \multicolumn{1}{c}{ PE } \\
\hline $16: 0$ & $17.1 \pm 0.6$ & $3.6 \pm 0.9$ & $16.1 \pm 1.1$ & $34.2 \pm 0.6$ & $6.8 \pm 0.8$ \\
$18: 0$ & $26.2 \pm 2.5$ & $24.3 \pm 1.5$ & $26.8 \pm 0.8$ & $15.5 \pm 0.6$ & $13.4 \pm 1.6$ \\
$18: 1_{\omega \triangleleft}$ & $9.8 \pm 1.2$ & $2.2 \pm 0.6$ & $6.9 \pm 0.7$ & $12.4 \pm 1.1$ & $9.3 \pm 1.0$ \\
$18: 1_{\omega\urcorner}$ & $2.5 \pm 0.6$ & $0.5 \pm 0.1$ & $1.9 \pm 0.2$ & $3.6 \pm 0.2$ & $2.9 \pm 0.1$ \\
$18: 2_{\omega 6}$ & $3.1 \pm 0.3$ & $0.5 \pm 0.1$ & $0.5 \pm 0.0$ & $1.6 \pm 0.3$ & $1.1 \pm 0.2$ \\
$20: 4_{\omega 6}$ & $9.1 \pm 1.0$ & $2.5 \pm 0.4$ & $28.1 \pm 1.5$ & $3.6 \pm 0.2$ & $11.2 \pm 0.6$ \\
$20: 5_{\omega 3}$ & $1.2 \pm 0.7$ & $0.9 \pm 0.2$ & $2.0 \pm 0.4$ & $0.9 \pm 0.2$ & $2.9 \pm 0.4$ \\
$22: 5_{\omega 3}$ & $3.2 \pm 1.0$ & $6.1 \pm 0.4$ & $1.0 \pm 0.2$ & $1.1 \pm 0.1$ & $4.8 \pm 0.3$ \\
$22: 6_{\omega 3}$ & $24.9 \pm 3.6$ & $57.5 \pm 2.8$ & $18.3 \pm 2.6$ & $21.2 \pm 0.7$ & $44.9 \pm 2.5$ \\
Ratio 22:6/20:4 & 2.7 & 23.0 & 0.7 & 5.9 & 4.0
\end{tabular}

Values are the average \pm SD of five individual samples, expressed as mole percent. Lipids were isolated by TLC, and their fatty acid composition was analyzed by GLC, as detailed in Materials and Methods. 


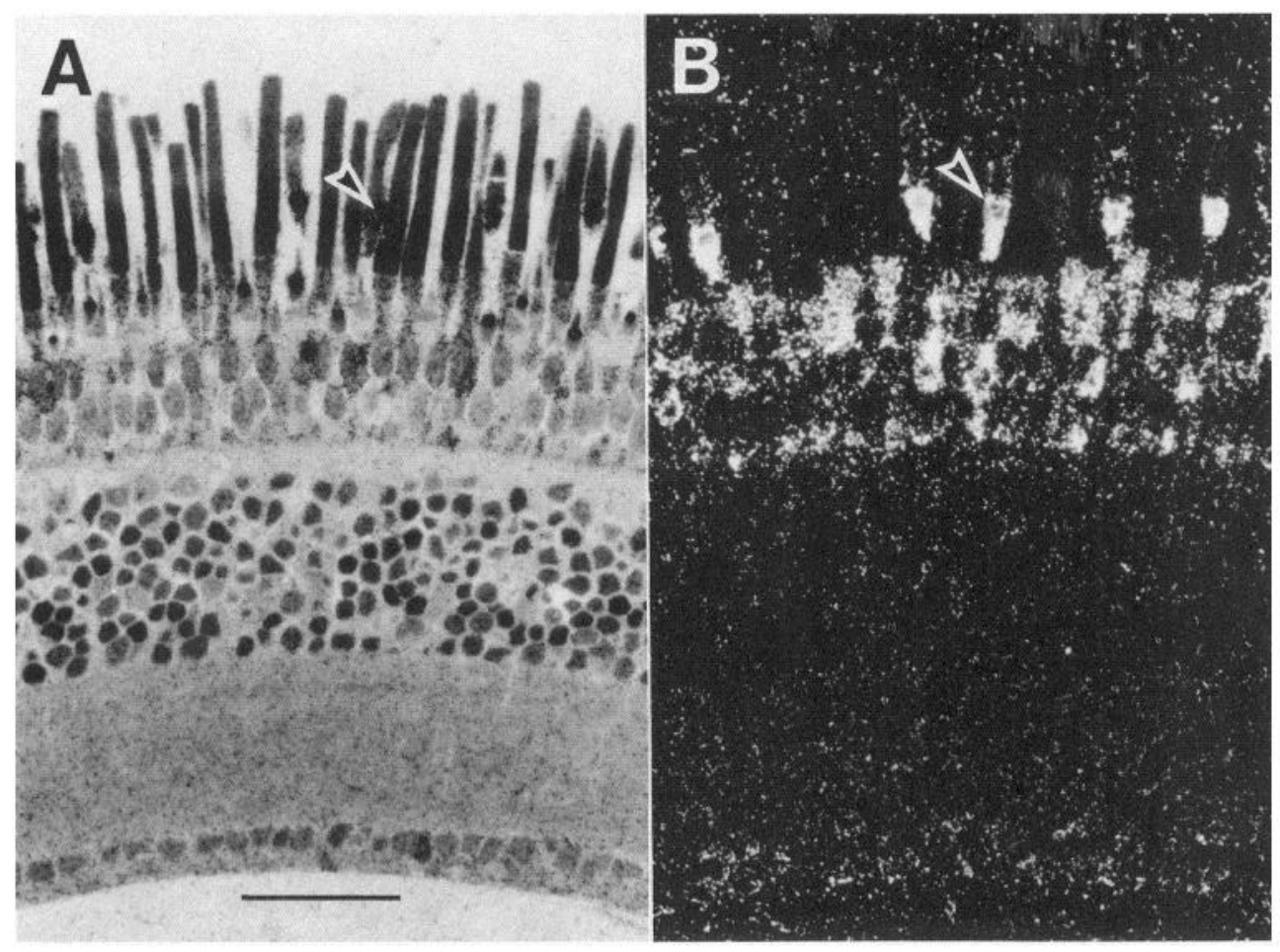

Figure 5. Autoradiographic profile of ${ }^{3} \mathrm{H}-22: 6$ distribution in frog retina. Retinas were labled in vitro with ${ }^{3} \mathrm{H}-22: 6$ $(2 \mu \mathrm{Cl} / \mathrm{ml}$; final concentration, $110 \mathrm{nM})$ for $6 \mathrm{hr}$. After conventional tissue preparation and embedding in plastic, $1-\mu \mathrm{m}$ sections were coated with NT-B2 autoradiographic emulsion, overexposed for 5 weeks to emphasize regional differences, and developed. The same section is shown by bright-field $(A)$ and dark-field $(B)$ microscopy. Note that the majority of the labeled $22: 6$ has accumulated within the photoreceptor cell layer, while only diffuse label can be seen throughout the neutral retina. $A r$ rowheads denote the highly labeled inner segments of 435-rod (blue-sensitive) photoreceptors. Scale bar, $50 \mu \mathrm{m}$. grains from outer segments, the rest of the photoreceptors, and neural retina demonstrated a distinctive time-dependent profile (Fig. $8 B$ ). At the earliest time points, the neural retina accumulated ${ }^{3} \mathrm{H}-22: 6$, reached a plateau between 1 and $2 \mathrm{hr}$, and showed a slight increase in uptake at later times. The photoreceptor inner segments accumulated 22:6 throughout the incubation times, but the uptake rate rapidly increased after $2 \mathrm{hr}$. Label also accumulated within ROSs with an uptake profile similar to, but smaller than, that of the inner segments. After 6 $\mathrm{hr}$ of incubation, $70 \%$ of total retinal labeling was observed in the rest of the photoreceptor cells (predominantly ellipsoids), while ROS and neural retina accounted for $23 \%$ and $7 \%$, respectively.

The frog has two types of rod photoreceptors (the green and the red rods, named for their reflectance characteristics) and two types of cones. Green rods are blue sensitive $(435 \mathrm{~nm})$ and red rods are green sensitive $(502 \mathrm{~nm})$ (Liebman and Entine, 1968). Cones are either green sensitive $(502 \mathrm{~nm})$ or red sensitive $(575$ $\mathrm{nm}$ ). We refer to these photoreceptors by the wavelength of the maximum absorbance of their visual pigments (Gordon and Dahl, 1990). These different cell types are morphologically distinct (Nilsson, 1964), making it easy to identify them. The outer segments of the 435-rods are shorter than those of the 502-rods and have inner segments that are displaced toward the RPE. The cone outer segments are much smaller than those of the rods and are located near the base of the ROS in the lightadapted state. The 575-cones all possess a large oil droplet in the distal region of the inner segment, while the 502-cones do not. The 502-cones are always paired with 575-cones; however, 575-cones also occur singly.

A differential uptake of ${ }^{3} \mathrm{H}-22: 6$ occurred among types of photoreceptor cells (Fig. 9). These differences were even more dramatic when the ellipsoid regions of the 435-rods, the 502rods, and the cones were compared (Fig. 7). The greatest accumulation was observed within the 435-rod cells. Less label was found in the 502-rods, while cone ellipsoid regions demonstrated only occasional activity.

Quantitation of the number of autoradiographic grains over equal areas of ellipsoid regions and outer segments of photoreceptor cells allowed the density of labeling to be compared as a function of time (Fig. 10). Both outer segments and ellipsoids (inner segments) of 435-rods showed two and three times greater density of labeling than the same regions in 502-rods. These differences were maintained throughout the incubations for both areas but were not apparent at the earliest times in the outer segments because of the low number of silver grains.

Table 2. Endogenous content of 22:6 chains and relative specific activity in retinal phospholipids

\begin{tabular}{clllll} 
& PA & PS & PI & PC & PE \\
\hline $22: 6$ content & $2.4 \pm 0.3$ & $41.1 \pm 2.4$ & $4.4 \pm 0.4$ & $79.3 \pm 5.1$ & $116.7 \pm 9.5$ \\
$\%{ }^{a}(\mathrm{a})$ & 1.0 & 16.9 & 1.8 & 32.5 & 47.9 \\
${ }^{3} \mathrm{H}-22: 6 \%$ (b) & 1.4 & 13.4 & 27.1 & 27.8 & 30.4 \\
Ratio b/a & 1.4 & 0.8 & 15.1 & 0.9 & 0.6
\end{tabular}

Values for 22:6 content are nmol fatty acid/mg protein \pm SD. Other details are as in Figure 1 and Table 1.

${ }^{a}$ Percent (\%) distribution of 22:6 mass and labeling recovered in individual phospholipids. 

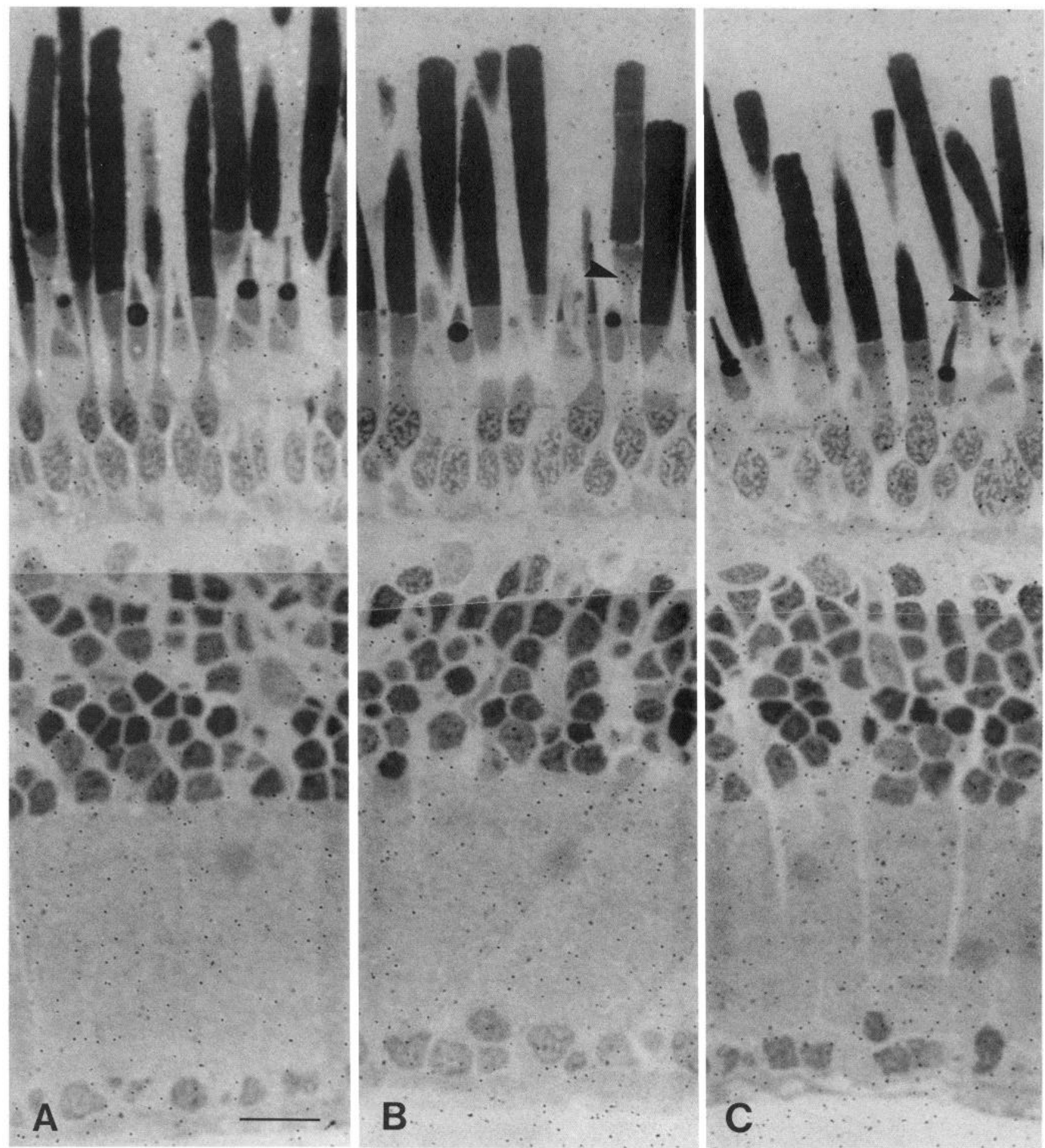

Figure 6. Autoradiographic profiles of ${ }^{3} \mathrm{H}-22: 6$ uptake by retinal cells as a function of time. Incubation times include 15 min $(A), 30$ min $(B), 1$ $\mathrm{hr}(C), 2 \mathrm{hr}(D), 4 \mathrm{hr}(E)$, and $6 \mathrm{hr}(F)$. This plate illustrates early labeling in the myoid region (arrowhead in $B$ ), followed by intracellular apical migration into the ellipsoids (arrowhead in $C$ ) and proximal migration to the synaptic terminals at later times. Scale bar, $20 \mu \mathrm{m}$.

Cone photoreceptor inner segments (ellipsoids) retained label only slightly above background level throughout the incubations (Fig. 10) and showed only $5 \%$ of the label found in 435 -rod cell ellipsoids. Thus, the density of labeling in 435-rod cells was 22 times greater than that seen in cone cells.

\section{Discussion}

Our data show that frog (Rana pipiens) retina incubated in vitro avidly takes up ${ }^{3} \mathrm{H}-22: 6$ over a biphasic time course and that the fatty acid is rapidly esterified, mainly into PI, PE, and PC. 

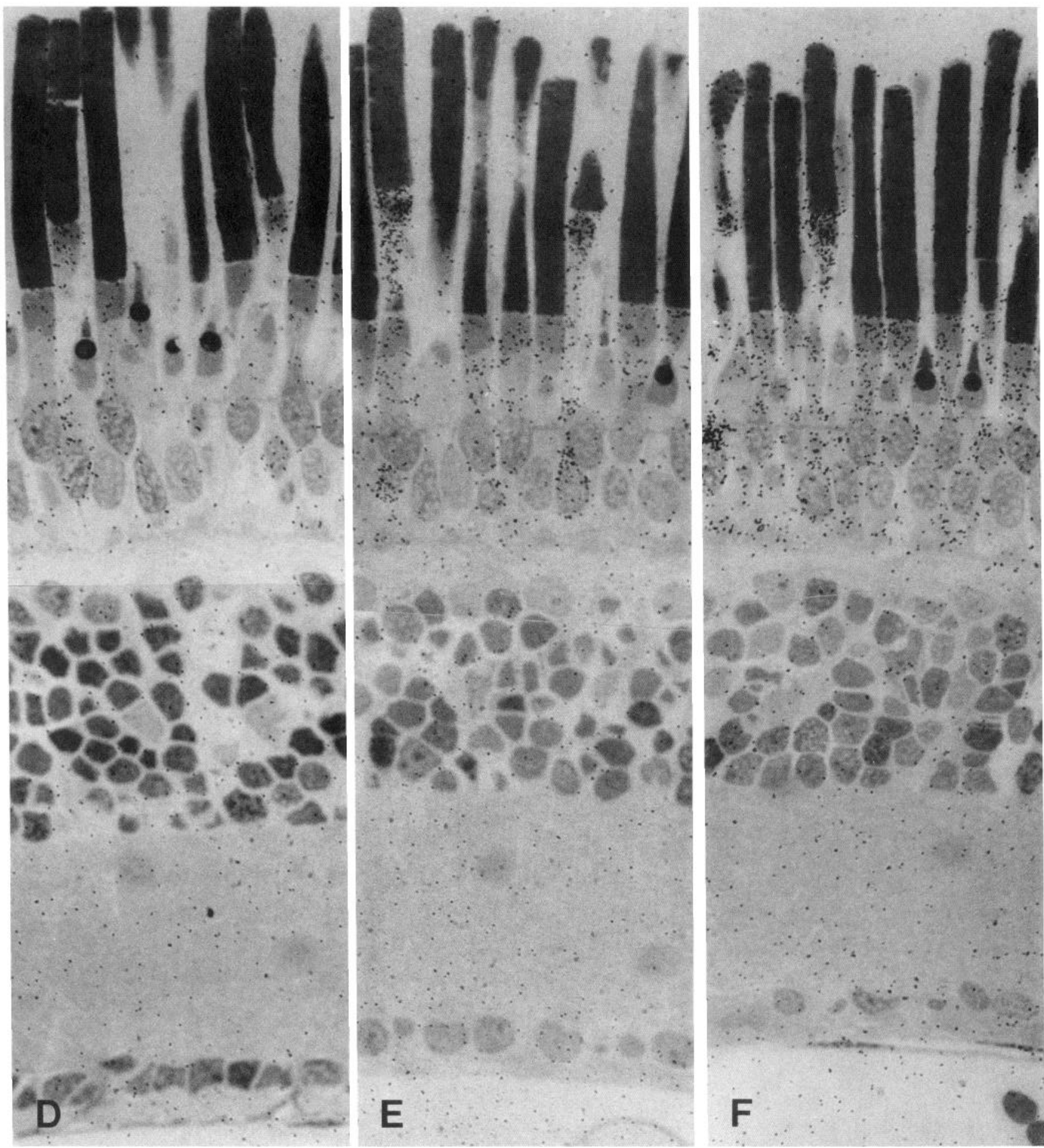

Autoradiographic analysis of the retinal label distribution as a function of time shows that (1) ${ }^{3} \mathrm{H}-22: 6$ labeling was selectively concentrated in photoreceptor cells, and (2) there was a differential uptake of ${ }^{3} \mathrm{H}-22: 6$ among rods and cones; that is, 435rods labeled more heavily than 502 -rods, while cone labeling was very low except in oil droplets of 575-cones.

When retinas were incubated with lower specific activity $22: 6$ (at $70 \mu \mathrm{M}$ final concentration), as compared to ${ }^{3} \mathrm{H}-22: 6(0.11$ $\mu \mathrm{M})$, a significant proportion of the label was free $22: 6(40 \%$ after $5 \mathrm{hr}$ of incubation), and PC and PE were the most heavily labeled phospholipids. When micromolar 22:6 was used, an accumulation of free ${ }^{14} \mathrm{C}-22: 6$ and high $\mathrm{PC}$ labeling in isolated retinal subcellular fractions, ROSs, and disks was reported (Giusto et al., 1986; Rotstein and Aveldaño, 1987a; Rotstein et 

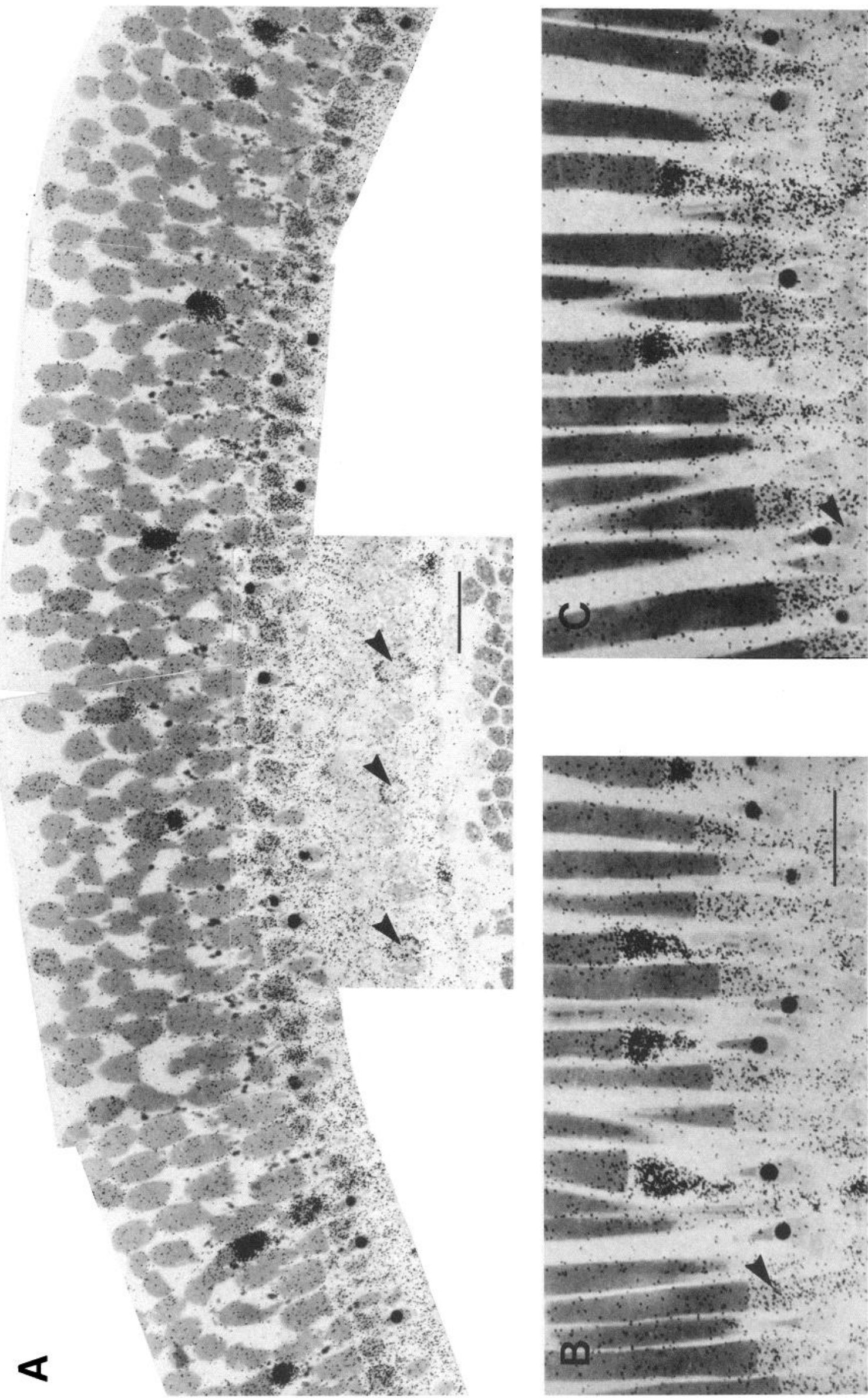

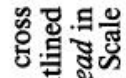

.

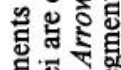

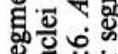

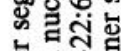

它空.品

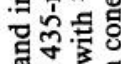

为

諘它

웡

迡导

는.

居和

응 훙

品

w.

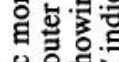

ㅎํㅇำ

를.

땞궁

을

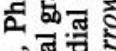

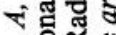

i. 욤

융 믈

है

它守客

生逑

边
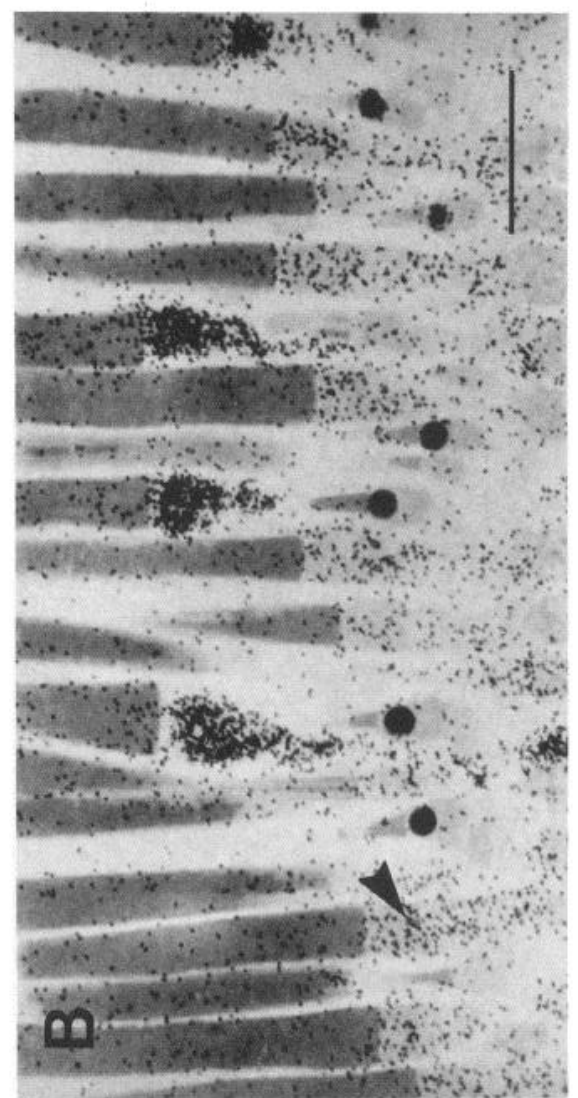

항 원

응즌

额

舟

o.

붕응

国焉

눌

ส

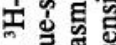

뜰 응

항 홍

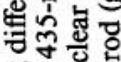

跑

의

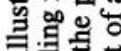

.

댒 동.

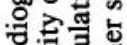

过急吉

娄轮

.

너ำ

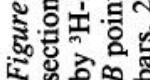



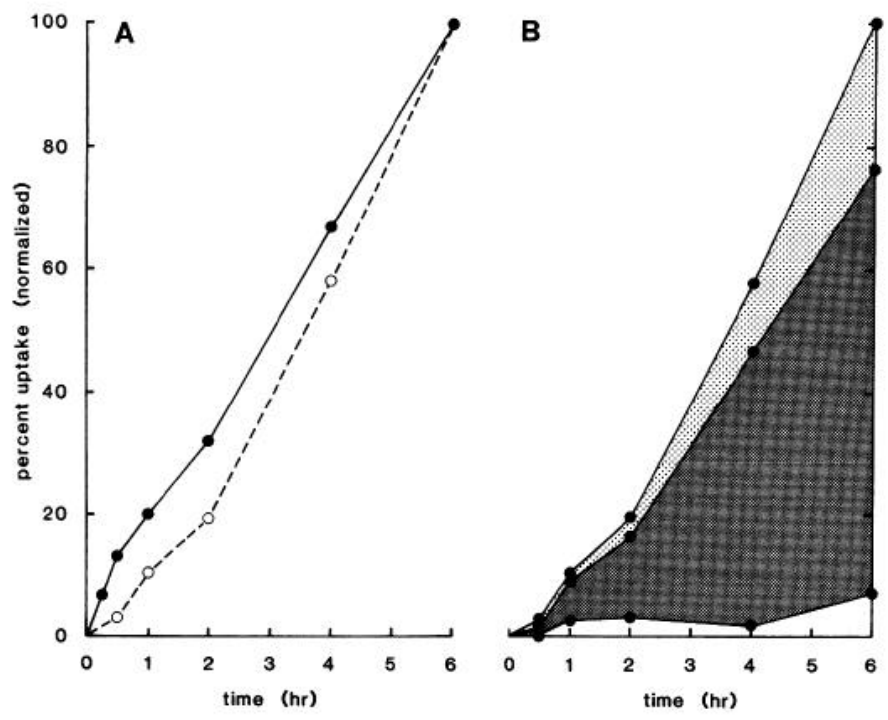

Figure 8. Uptake sequence and distribution of 22:6 in frog retina. $A$, Comparison of time-dependent ${ }^{3} \mathrm{H}-22: 6$ uptake by frog retina followed by biochemical and autoradiographic techniques. Similar profiles are obtained when values at different incubation times are expressed as a percentage with respect to the maximum value at $6 \mathrm{hr}$ [total dpm $/ \mathrm{mg}$ protein, biochemistry ( () , and total number of silver grains/unit tissue area, autoradiography $(\mathrm{o})$ ]. Note that biochemical and autoradiographic data reveal similar rates of uptake and suggest that the two kinds of data can be compared. $B$, Accumulation of ${ }^{3} \mathrm{H}-22: 6$ in different retinal regions as a function of time. Grain counts for total retina (upper line), photoreceptor outer segments (lightly shaded area), rest of photoreceptors (heavily shaded area), and neural retina (open area) have been plotted as a function of time.

al., 1987). Therefore, low-specific-activity $22: 6$, because of its relatively high mass, leads to accumulation of free $22: 6$ in retinal membranes. Under conditions of 22:6 abundance, the existence of high- $K_{m}$ acylating enzymes could cause diversion of 22:6 into lipid storage forms (e.g., TAGs). However, recent studies suggest that accumulation of 22:6 inside the cells may exert a stimulatory effect at the level of phosphatidate-phosphohydrolase, shifting the de novo pathway of lipid synthesis toward TAGs and zwitterionic lipids (Rodriguez de Turco et al., 1991).

In the nervous system, endogenous free fatty acids, mainly polyunsaturated fatty acids, do not accumulate (Bazan et al., 1986) as a result of active acyl-CoA synthetases, transferases, and fatty acid-binding proteins that sequester the free fatty acids and prevent membrane damage. The nanomolar concentrations of free 22:6 used in these experiments are relatively high. Docosahexaenoic acid, which is probably linked to plasma lipoproteins that are supplied by the liver (Bazan et al., 1985b; Scott and Bazan, 1989), can be selectively and efficiently taken up from the choriocapillaris by the RPE (Gordon and Bazan, 1990). The presence of low-density lipoprotein (LDL) receptors in bovine RPE suggests this possibility (Hayes et al., 1989). How the handling of this fatty acid inside RPE cells, and its subsequent delivery to retinal photoreceptor cells (either free or as a lipoprotein complex), are accomplished is not completely understood, but it may involve the presence of an LDL-like receptor in the inner segments (Bazan and Cai, 1990). The presence of 22:6 bound covalently or noncovalently to interphotoreceptor matrix proteins, including retinoid-binding protein, suggests that these proteins could be involved in the transport of 22:6 from RPE cells to photoreceptor cells (Bazan et al., 1985a).

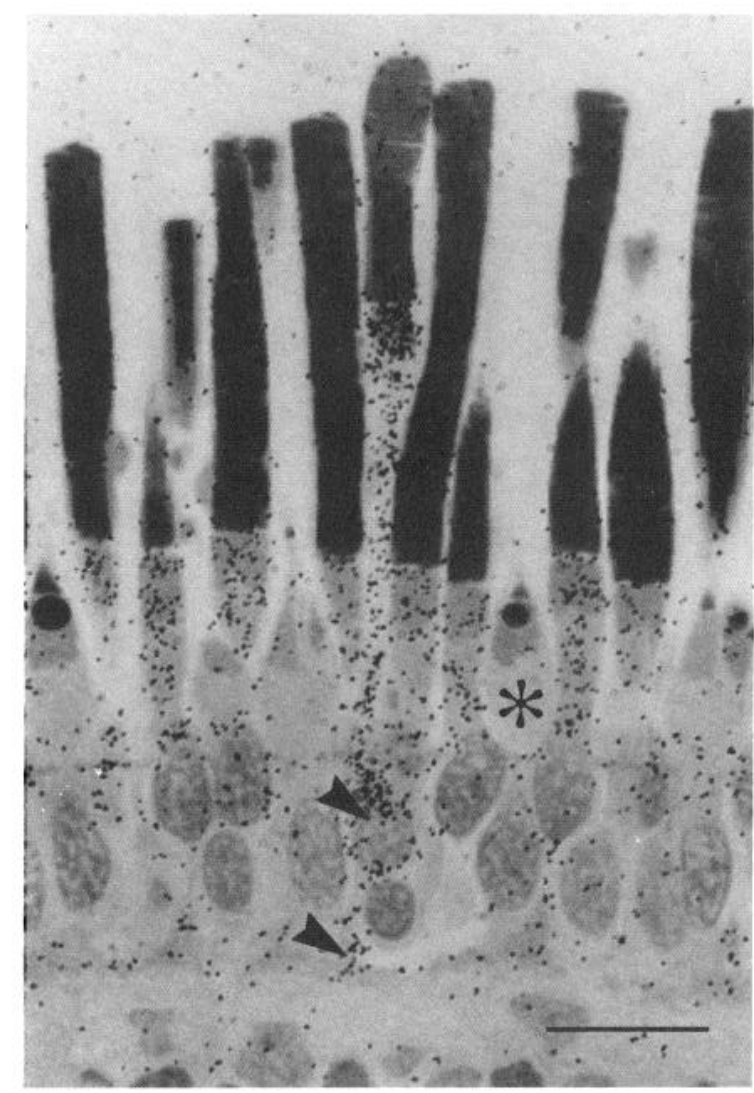

Figure 9. Autoradiograph illustrating, in greater detail, the differential labeling of frog retinal photoreceptors after $4 \mathrm{hr}$ of incubation. After initial uptake in the myoid region of rod cells, label has accumulated in the ellipsoid region of the inner segment and throughout the basal portions of the inner segment as ${ }^{3} \mathrm{H}-22: 6$ is transported to the synaptic terminal (lower arrowhead). Heavy labeling is also apparent in the perinuclear cytoplasm (upper arrowhead). All rods have similar profiles of intracellular labeling, but 435-rods (arrowheads) accumulate much more 22:6 than 502-rods. Myoid regions of cone photoreceptors demonstrate no significant label (asterisk). Scale bar, $20 \mu \mathrm{m}$.

Our present study shows that isolated frog retinas, incubated in the presence of the labeled precursor (in nanomolar concentration), actively take up the fatty acid. Except for a transient free 22:6 accumulation within the first hour of incubation, 22:6 uptake was coupled to a very active activation-acylation mechanism, since essentially all of the recovered labeled fatty acid had been esterified. A low- $K_{m}$ docosahexaenoyl-CoA synthetase in retinal microsomes may be linked to the efficient retention of polyunsaturated fatty acids in retinal cells (Reddy and Bazan, 1984, 1985). At the end of $6 \mathrm{hr}$ incubation, only one-third of the total radioactivity added per retina was recovered in the tissue, suggesting that the rate of activation-esterification was a major factor involved in the regulation of 22:6 uptake. Furthermore, free diffusion of 22:6 is probably not the main mechanism involved in its uptake by retinal cells when it is present in nanomolar concentrations, as evidenced by the high degree of selectivity of the uptake. The neural retina at $6 \mathrm{hr}$ of incubation contained only $8 \%$ of the total ${ }^{3} \mathrm{H}-22: 6$, indicating that photoreceptor cells most avidly took up and concentrated 22:6 into their phospholipids. A sustained increase in labeling within photoreceptor cells was coincident with the second phase of 22: 6 uptake following $1 \mathrm{hr}$ of incubation. 


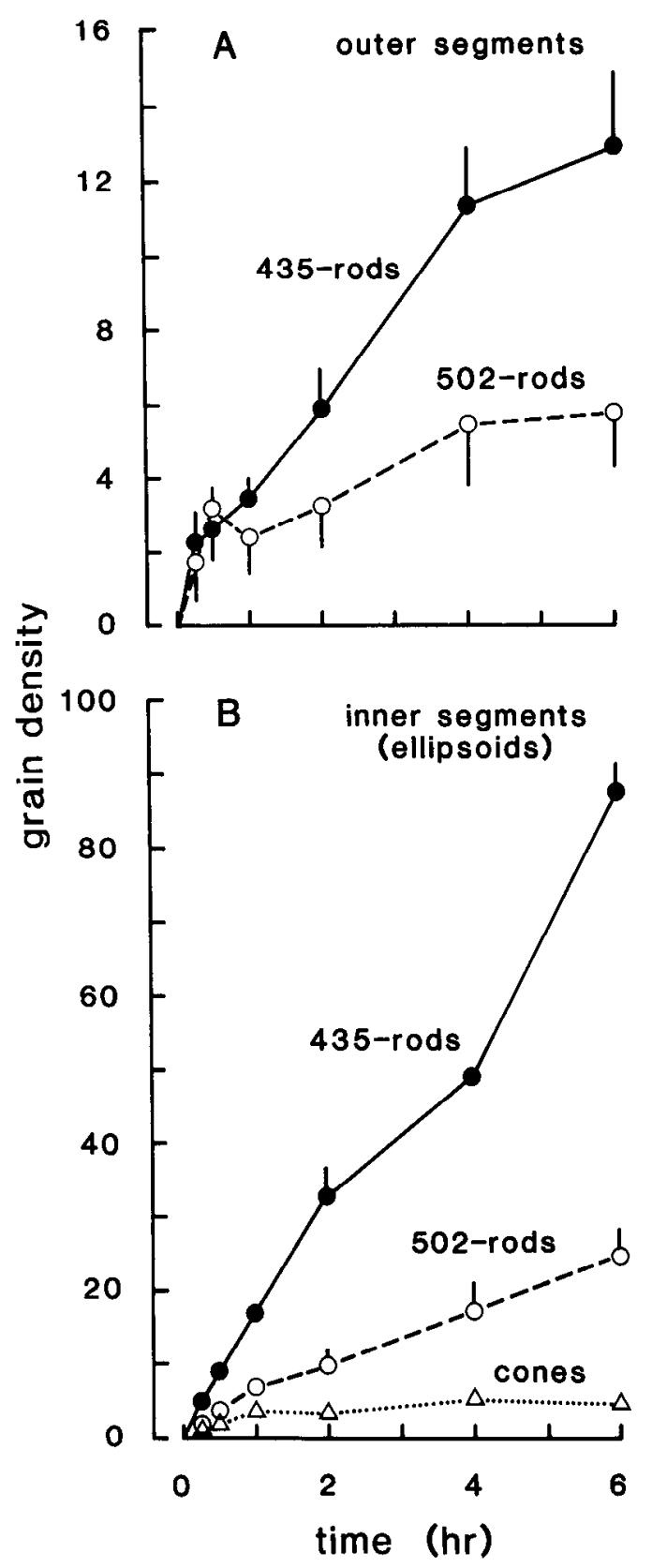

Figure 10. Differences in the density of labeling in outer and inner segments of photoreceptor cells as a function of time. $A, 435$-rod photoreceptor outer segments accumulate twice as much label as do 502rod outer segments from $2 \mathrm{hr}$ onward. $B, 435$-Rod inner segments (ellipsoids) accumulate three times the labeling of 502-rods, and 22 times as much as the cones. All points represent the mean value \pm SD from at least three individual determinations.

The myoid is where the bulk of endoplasmic reticulum is located and where de novo synthesis of lipids occurs (Mercurio and Holtzman, 1982). This portion of the cell is the first part of the photoreceptor cells to show labeling. Activation of 22:6 to 22:6-CoA (Reddy and Bazan, 1984, 1985) and its esterification in the de novo biosynthetic pathway of phospholipids also take place in that portion of the cell (Kaladi et al., 1984). In fact, 22:6 is introduced into lipids during de novo synthesis of PA (Bazan et al., 1984) and by deacylation-reacylation during the retailoring of phospholipid acyl groups. The initial high labeling of PA described in this study further supports the idea that this de novo pathway is actively involved in 22:6 esterification into membrane lipids. The synthesis of dipolyunsaturated molecular species of phospholipids that accumulate in the disk membranes of ROSs may occur by a combination of the de novo pathway and the deacylation-reacylation reactions. The latter may contribute to the introduction of the second 22:6 moiety into dipolyunsaturated molecular species. Synthesis and remodeling of PC, PE, and PS likely occur before these phospholipids become incorporated into the disks of ROSs (Rotstein and Aveldaño, 1987b).

An active, bidirectional cellular trafficking of 22:6-containing molecules takes place in the myoid: one route moves toward the base of the outer segment (ellipsoid region); the other, to the synaptic terminals of the photoreceptor cells. The ellipsoid is densely packed with mitochondria, favoring their intimate and transient contact with lipid vesicles traveling through this area prior to their addition to the basal infoldings of the ROS plasma membrane. Analysis of the endogenous content and ${ }^{14} \mathrm{C}$ labeling of 22:6-containing lipids, especially of the dipolyunsaturated forms, in bovine retina has shown that there is a concentration and labeling gradient between endoplasmic reticulum and ROS (Rotstein and Aveldaño, 1987a,b), where the polyunsaturated species accumulate in the disk membranes (Aveldaño, 1989; Boesze-Battaglia and Albert, 1989). Mitochondrial fractions showed intermediate 22:6 content (Rotstein and Aveldaño, 1987a). It has been suggested that mitochondria could play a role in the remodeling of lipid molecules, mainly PC, PE, and PS, before they are delivered for disk membrane synthesis (Rotstein and Aveldaño, 1987b). In the present study, there was no labeling assessable by autoradiography at the base of the ROSs at this early time point in vitro. However, in vivo, the migration of ${ }^{3} \mathrm{H}-22: 6$ into ROS disks over a period of days has been shown (Gordon and Bazan, 1990).

The use of ${ }^{3} \mathrm{H}-22: 6$ (nanomolar range) of very high specific activity, instead of ${ }^{14} \mathrm{C}-22: 6$ (micromolar range), has shown for the first time that there is a well-controlled uptake of $22: 6$ by photoreceptor cells coupled to the very active labeling of a small pool of 22:6-PI. The endogenous content of 22:6 in retinal PI from frogs is relatively high (Table 1), as compared to that of mammals (Anderson, 1970; Aveldaño and Bazan, 1974; Aveldaño de Caldironi and Bazan, 1980). PI labeling with 22:6 after $2 \mathrm{hr}$ of retinal incubation is higher than PC or PE labeling, indicating that a high-affinity $22: 6$ uptake activating-acylating system is involved. It is possible that the $22: 6$ introduced through the de novo synthesis of PA may give rise to the 22:6-PI. In fact, labeling of bovine and frog retinas with ${ }^{14} \mathrm{C}$-glycerol has revealed a very high biosynthetic rate of hexa- and supraene molecular species of PI (Aveldaño de Caldironi and Bazan, 1980). In addition, high PI labeling was also observed after short incubations of monkey and human retinas with ${ }^{3} \mathrm{H}-22: 6$ (Rodriguez de Turco et al., 1990). The formation of phosphorylated derivatives of 22:6-PI is being studied. Inositol lipids, which are engaged in cell signal transduction through the generation of messengers for intracellular $\mathrm{Ca}^{2+}$ ionization and protein $\mathrm{ki}$ nase $\mathrm{C}$ activation, are enriched in arachidonoyl chains in all cells studied to date (Bazan, 1989). It is possible that there is a unique signaling pathway in photoreceptor cells that involves 22:6-containing phosphoinositides.

In the present study, the cellular distribution of ${ }^{3} \mathrm{H}-22: 6-$ labeled lipids in the retina demonstrated a well-defined selectivity among photoreceptor cell types. Labeling prevailed in the 
inner segments of the 435-rods, while 502-rod inner segments concentrated only about one-third of this amount. The inner segment cytoplasm of the 502- and 575-cones did not accumulate label; however, 22:6 labeling was found concentrated within cone oil droplets, presumably esterified into TAGs and cholesterol esters. Most of the ${ }^{3} \mathrm{H}-22: 6$ phospholipids represent molecules that have been synthesized for use in membrane biogenesis within rod photoreceptor cells. This differential labeling might be related to structural and functional differences among the photoreceptor cell types.

The ellipsoids of photoreceptors in goldfish (Marc and Sperling, 1976) and monkey (Marc and Sperling, 1977) can be differentially stained with nitro-blue tetrazolium (a metabolic marker) and labeled with ${ }^{3} \mathrm{H}$-2-deoxyglucose following chromatic stimulation specific for each cell type (Basinger et al., 1979). Moreover, blue-sensitive cones of the primate retina can be selectively stained by Procion dyes (de Monasterio et al., 1981; McCrane et al., 1983). Biochemical differences between rods and cones include distinct transducins (Lerea et al., 1986), cGMP phosphodiesterases (Hurwitz et al., 1985; Gillespie and Beavo, 1988; Hamilton and Hurley, 1990), and rhodopsins (Dartnall, 1953; Liebman and Entine, 1968; Nathans et al., 1986). Bunt and Klock (1980) showed in 12 species that cone photoreceptors could be distinguished from rod cells with ${ }^{3} \mathrm{H}$ fucose, and Balkema and Bunt-Milam (1982) used this technique to describe cone outer segment shedding in the goldfish retina. Hollyfield et al. (1984) differentiated two rod populations in Xenopus with this label. The biggest and most dramatic functional differences have been shown by electrophysiology (Baylor, 1987).

In spite of these major differences between rod and cone photoreceptors, little is known about the roles that their lipids play in the daily function and renewal of rod and cone photoreceptor membranes. Our present results document that major differences exist in the distribution or metabolism of 22:6-rich phospholipids of rod and cone types within the frog retina. While frog cone photoreceptors tend not to label with ${ }^{3} \mathrm{H}-22: 6$, cone photoreceptors of humans and squirrel monkeys take up similar amounts (Rodriguez de Turco et al., 1990). This suggests that a basic difference exists between homeothermic and poikilothermic cone cells. We have no explanation at present for the high labeling of the 435-rod cells in the frog retina. It is perhaps significant that a cone marker, ${ }^{3} \mathrm{H}$-fucose, also labels the minor (blue-sensitive) rod in Xenopus (Hollyfield et al., 1984) and differentially labels the two rod types in Rana (Bunt and Klock, 1980).

The cone photoreceptor cells of Rana pipiens may incorporate less label than the rod cells because they have proportionally less membrane to maintain and may have lower renewal rates. It is possible that the uptake and/or metabolic mechanisms are different within the two cell types or that the cone cells utilize different phospholipids that contain less 22:6. Labeling of the 575-cone oil droplet may occur if this structure contains 22:6cholesterol ester and/or 22:6-TAG.

The ${ }^{3} \mathrm{H}-22: 6$ labeling of the frog retina occurs within two separate retinal regions that normally are isolated from one another. The outer chamber, bounded by Bruch's membrane and the outer limiting membrane of the Müller cells, encloses the photoreceptor outer and inner segments. The inner chamber, isolated by the outer and inner limiting membrane of the Müller cells, contains the neural elements and all synaptic regions (Fig. 1). Initial, low-level labeling occurs in the neural retina, followed by rapid uptake into the photoreceptor inner segments. The neural retina saturates quickly, while the photoreceptors continuc to incorporatc 22:6, suggesting that two different mechanisms are present. This also suggests that photoreceptor requirements are much higher than those of the neural retina or that differences exist in the accessibility of the two chambers (Fig. 1). Since photoreceptors continue to accumulate label to a much greater extent than do the underlying neural layers, even under in vivo conditions where Bruch's membrane and the RPE cells are intact (Gordon and Bazan, 1990), it seems unlikely that accessibility alone could account for the observed distribution of retinal 22:6. As discussed above, differential cellular labeling also occurs within the photoreceptor layer.

In summary, we show in the present study that frog retinas incubated in vitro with ${ }^{3} \mathrm{H}-22: 6$ in nanomolar mass concentration efficiently incorporated this precursor into phospholipids, preferentially labeling photoreceptor cells. Moreover, a preferential uptake of ${ }^{3} \mathrm{H}-22: 6$ by 435 -rods, as compared with $502-$ rods, was observed, while significant labeling of cones was only detectable in the oil droplets of the 575-cone type. Differences in the magnitude and time course of labeling between the photoreceptors and the neurons of the retina, a preferential uptake of ${ }^{3} \mathrm{H}-22: 6$ by 435 -rod cells, and a very high labeling of PI suggest a unique role for 22:6 in the retina.

\section{References}

Anderson RE (1970) Lipids of ocular tissues. IV. A comparison of the phospholipids from the retina of six mammalian species. Exp Eye Res 10:339-344.

Aveldaño MI (1989) Dipolyunsaturated species of retina phospholipids and their fatty acids. In: Biomembranes and nutrition, Vol 195 (Léger CL, Béréziat G, eds), pp 87-96. Paris: Colleque INSERM.

Aveldaño MI, Bazan NG (1974) Free fatty acids, diacyl- and triacylglycerols, and total phospholipids in vertebrate retina: comparison with brain, choroid, and plasma. J Neurochem 23:1127-1135.

Aveldaño MI, Bazan NG (1977) Acyl groups, molecular species, and labeling by ${ }^{14} \mathrm{C}$-glycerol and ${ }^{3} \mathrm{H}$-arachidonic acid of vertebrate retina glycerolipids. Adv Exp Med Biol 83:397-404.

Aveldaño de Caldironi MI, Bazan NG (1980) Composition and biosynthesis of molecular species of retina phosphoglycerides. Neurochem Int 1:381-392.

Balkema GW, Bunt-Milam AH (1982) Cone outer segment shedding in the goldfish retina characterized with the ${ }^{3} \mathrm{H}$-fucose technique. Invest Ophthalmol Vis Sci 23:319-331.

Basinger SF, Gordon WC, Lam DMK (1979) Differential labeling of retinal neurons by ${ }^{3} \mathrm{H}$-2-deoxyglucose. Nature 280:682-684.

Baylor D (1987) Photoreceptor signals and vision. Invest Ophthalmol Vis Sci 28:34-49.

Bazan HEP, Sprecher H, Bazan NG (1984) De novo biosynthesis of docosahexaenoyl-phosphatidic acid in bovine retinal microsomes. Biochim Biophys Acta 796:11-19.

Bazan NG (1989) Metabolism of arachidonic acid in the retina and retinal pigment epithelium: biological effects of oxygenated metabolites of arachidonic acid. In: The ocular effects of prostaglandins and other eicosanoids (Bito L, ed), pp 15-37. New York: Liss.

Bazan NG, Cai F (1990) Internalization of apolipoprotein E (APO E) in rod photoreceptor cells by a low density lipoprotein receptor. Invest Ophthalmol Vis Sci [Suppl] 31:471.

Bazan NG, Reddy TS (1985) Retina. In: Handbook of neurochemistry, Vol 8 (Lajtha A, ed), pp 507-575. New York: Plenum.

Bazan NG, Reddy TS, Redmond TM, Wiggert B, Chader GJ (1985a) Endogenous fatty acids are covalently and noncovalently bound to interphotoreceptor retinoid-binding protein in the monkey retina. J Biol Chem 260:13677-13680.

Bazan NG, Birkle DL, Reddy TS (1985b) Biochemical and nutritional aspects of the metabolism of polyunsaturated fatty acids and phospholipids in experimental models of retinal degeneration. In: Retinal degeneration: experimental and clinical studies (LaVail MM, Anderson RE, Hollyfield J, eds), pp 159-187. New York: Liss. 
Bazan NG, Reddy TS, Bazan HEP, Birkle DL (1986) Metabolism of arachidonic and docosahexaenoic acids in the retina. Prog Lipid Res 25:595-606.

Boesze-Battaglia K, Albert AD (1989) Fatty acid composition of bovine rod outer segment plasma membrane. Exp Eye Res 49:699-701.

Bunt AH, Klock IB (1980) Comparative study of ${ }^{3} \mathrm{H}$-fucose incorporation into vertebrate photoreceptor outer segments. Vision Res 20:739-747.

Dartnall HJA (1953) The interpretation of spectral sensitivity curves. Br Med Bull 9:24-30.

de Monasterio FM, Schein SJ, McCrane EP (1981) Staining of bluesensitive cones of the macaque retina by a fluorescent dye. Science 213:1278.

Fliesler S, Anderson RE (1983) Chemistry and metabolism of lipids in the vertebrate retina. Prog Lipid Res 22:79-131.

Fliesler SJ, Basinger SF (1987) Monensin stimulates glycerolipid incorporation into rod outer segment membranes. J Biol Chem 262: 17516-17523.

Gillespie PG, Beavo JA (1988) Characterization of a bovine cone photoreceptor phosphodiesterase purified by cyclic GMP-sepharose chromatography. J Biol Chem 236:8133-8141.

Giusto NM, Illincheta de Boschero M, Sprecher H, Aveldaño MI (1986) Active labeling of phosphatidylcholines by $\left[1-{ }^{14} \mathrm{C}\right]$ docosahexaenoate in isolated photoreceptor membranes. Biochim Biophys Acta 860: 137-148.

Gordon WC, Bazan NG (1990) Docosahexaenoic acid utilization during rod photoreceptor cell renewal. J Neurosci 10:2190-2204.

Gordon WC, Dahl NA (1990) Light absorbed by 575-cones triggers rod disc shedding in the frog retina. Visual Neurosci 4:95-98.

Hamilton SE, Hurley JB (1990) A phosphodiesterase inhibitor specific to a subset of bovine retinal cones. J Biol Chem 265:11259-11264.

Hayes KC, Lindsey S, Stephan ZF, Brecker D (1989) Retinal pigment epithelium possesses both LDL and scavenger receptor activity. Invest Ophthalmol Vis Sci 30:225-232.

Hollyfield JG, Rayborn ME, Rosenthal J (1984) Two populations of rod photoreceptors in the retina of Xenopus laevis identified with ${ }^{3} \mathrm{H}$ fucose autoradiography. Vision Res 24:777-782.

Hurwitz. RL, Bunt-Milam AH, Chang ML, Beavo JA (1985) cGMP phosphodiesterase in rod and cone outer segments of the retina. $J$ Biol Chem 260:568-573.

Kaladi S, Reddy TS, Bazan HEP (1984) Acylation and activation of docosahexaenoic acid (22:6) in retinal and pigment epithelium microsomal fractions. Invest Ophthalmol Vis Sci [Suppl] 25:61.

Lerea CL, Somers DE, Hurley JB, Klock IB, Bunt-Milam AH (1986) Identification of specific transducin $\alpha$-subunits in retinal rod and cone photoreceptors. Science 234:77-80.

Liebman PA, Entine $G$ (1968) Visual pigments of frog and tadpole (Rana pipiens). Vision Res 8:761-775.

Marc RE, Sperling HG (1976) The chromatic organization of the goldfish cone mosaic. Vision Res 16:1211-1224.

Marc RE, Sperling HG (1977) Chromatic organization of primate cones. Science 196:454-456.

Marcheselli VL, Bazan NG (1990) Quantitative analysis of fatty acids in phospholipids, diacylglycerols, free fatty acids, and other lipids. J Nutr Biochem 1:231-237.

McCrane EP, de Monasterio FM, Schein SJ, Caruso RC (1983) Non- fluorescent dye staining of primate blue cones. Invest Ophthalmol Vis Sci 24:1449-1455.

Mercurio AM, Holtzmann E (1982) Ultrastructural localization of glycerolipid synthesis in rod cells of the isolated frog retina. J Neurocytol 11:295-322.

Nathans J, Thomas D, Hogness DS (1986) Molecular genetics of human color vision: the genes encoding blue, green, and red pigments. Science 232:193-202.

Neuringer M, Connor WE, Van Petten C, Barstad L (1984) Dietary omega-3 fatty acid deficiency and visual loss in infant rhesus monkeys. $\mathrm{J}$ Clin Invet 73:272-276.

Neuringer M, Connor WE, Lin DS, Barstad L, Luck S (1986) Biochemical and functional effects of prenatal and postnatal omega-3 fatty acid deficiency on retina and brain in rhesus monkeys. Proc Nat Acad Sci USA 83:4021-4025.

Nilsson SEG (1964) An electron microscopic classification of the retinal receptors of the leopard frog (Rana pipiens). J Ultrastruct Res 10:390-416.

Reddy TS, Bazan NG (1984) Synthesis of arachidonoyl coenzyme A and docosahexaenoyl coenzyme $A$ in retina. Curr Eye Res 3:12251232.

Reddy TS, Bazan NG (1985) Synthesis of docosahexaenoyl-, arachidonoyl-, and palmitoyl-coenzyme $A$ in ocular tissue. Exp Eye Res 41: 87-95.

Rodriguez de Turco EB, Gordon WC, Bazan NG (1990) Preferential uptake and metabolism of docosahexaenoic acid in membrane phospholipids from rod and cone photoreceptor cells of human and monkey retinas. J Neurosci Res 27:522-532.

Rodriguez de Turco EB, Gordon WC, Bazan NG (1991) Modulation of uptake and metabolism of ${ }^{3} \mathrm{H}-\mathrm{DHA}$ in retina as a function of extracellular concentration of free DHA. Invest Ophthalmol Vis Sci [Suppl] 32:702.

Rotstein NP, Aveldaño MI (1987a) Labeling of lipids of retina subcellular fractions by $\left[1-{ }^{14} \mathrm{C}\right]$ eicosatetraenoate $(20: 4(\mathrm{n}-6))$, docosapentaenoate $(22: 5(n-3))$, and docosahexaenoate $(22: 6(n-3))$. Biochim Biophys Acta 921:221-234.

Rotstein NP, Aveldaño MI (1987b) Labeling of phosphatidylcholines of retinal subcellular fractions by $\left[1-{ }^{14} \mathrm{C}\right]$ eicosatetraenoate $(20: 4, \mathrm{n}-6)$, docosapentaenoate $(22: 5, n-3)$, and docosahexaenoate $(22: 6, n-3)$. Biochim Biophys Acta 921:235-244.

Rotstein NP, Ilincheta de Boschero MG, Giusto NM, Aveldaño MI (1987) Effects of aging on the composition and metabolism of docosahexaenoate-containing lipids of retina. Lipids 22:253-260.

Scott BL, Bazan NG (1989) Membrane docosahexaenoate is supplied to the developing brain and retina by the liver. Proc Natl Acad Sci USA 86:2903-2907.

Wheeler TG, Benolken RM, Anderson RE (1975) Visual membranes: specificity of fatty acid precursors for the electrical response to illumination. Science 188:1312-1314.

Wiegand RD, Anderson RE (1983) Phospholipid molecular species of frog rod outer segment membranes. Exp Eye Res 37:159-173.

Young RW (1974) Biogenesis and renewal of visual cell outer segment membranes. Exp Eye Res 18:215-223.

Young RW (1976) Visual cells and the concept of renewal. Invest Ophthalmol 15:700-725. 